remuneration. The opportunity to increase income through additional maternity care is, at present, open to all doctors giving medical services. True, there is a slightly increased payment given to those with added qualifications and experience. (It is, after all, the only branch of medicine dealing with a predominantly normal process in the young and healthy.)

The second paragraph of the letter must be more carefully examined. The idea of the additional experience and qualifications in other branches of medicine is usually to obtain a higher appointment in the subject concerned and is not done with any view to general practice. It is sometimes a disadvantage, as it tends to imply that a man has got "stuck" in one specialty. An increased basic knowledge of obstetrics, and a diploma, can be carried without any intention of specialization and for sole use in general practice. There are still appointments for clinical assistants in some of the subjects mentioned which would certainly give a few more pennies. $-I$ am, etc.,

Bromley, Kent.

P. H. BROWNE.

\section{Association Notices}

\section{ARMAGH AND WEST DOWN DIVISION}

Notice is hereby given by the Council to all concerned that the County Armagh Division and the West Down Division have been amalgamated to form the Armagh and West Down Division.

\section{P. Stevenson,} Secretary.

\section{Diary of Central Meetings}

\section{OCTOBER}

18 Tues. Central Consultants and Specialists Executive,

18 Tues. 10.45 a.m.

19 Wed. Financial Advisory Committee, 12 noon.

19 Wed. Journal Committee, 2 p.m.

19 Wed. Finance Committee, 3 p.m.

19 Wed. Finance Committee, 3 p.m.

20 Thurs. G.M.S. Committee, 10.30 a.m. 2 p.m

21 Fri. Radiologists Group Committee, 2 p.m.

25 Tues. Staff Side, 10 a.m.

25 Tues Joint Consultants Committee (to follow above)

Committee B. Medical Whitley Council, 2 p.m.

26 Wed. Council, 10 a.m.

27 Thurs. Hospitals Suhcommittee, General Medical Services Committee, 2 p.m.

\section{Branch and Division Meetings to be Held}

Argyll and Bute Division.-At Argyll and Bute Hospital, Sunday, October 23, 2.30 p.m., general meeting followed by presentation of three films. Preceded by luncheon at the Stag Hotel.

Birmingham Division.-At 36 Harborne Road, Edgbaston, Tuesday, October 18, 8.30 p.m., Dr. Keith Simpson: "Poisoning in Practice" (illustrated).

CARDIFP Division.--Joint meeting with South Wales and Monmouthshire Branch at Cardiff Royal Infirmary, Thursday, Octoher 20,3 p.m., clinical meeting.

DarTFord Division.- Thursday, October 20, visit to Wellcome Research Lahoratories at Beckenham. Meet at Laboratories, 12.30 p.m. (Lunch at Queen's Hotel, Norwood, 2.30 p.m.) Visit to end at 4.30 p.m.

Duncaster Division and Doncaster Medical Society.-At the Mansion House, Thursday, Octoher 20, 7 for 7.30 p.m., "Ladies' Night " hanquet and hall. Friends invited.

EAST Herts Division.-Ai Hertford County Hospital, Thursday, Octoher $20,8.30$ p.m. clinical meeting

Glossop Divisinn.-Ai Social Cluh. Eliison Street. Glossop, Monday, October 17. 8.45 p.m., annual general meeting. Election of officers. etc.

Gloucestershire Branch.-At Gloucester Cathedral. Sunday

Octoher 23. 3 p.m. St Luke's Tide Service for doctors and nurses Preacher, Bishop of Malmeshury.

GuILDFORD Division.-At St. Luke's Hospital, Guildford, Thursday, October 20, 8.15 p.m., clinical meeting.
Kensington and Hammersmith Division.-At Hammersmith Hospital (Lower Lecture Theatre), Ducane Road London W. Friday, October 21, 8.30 p.m. B.M.A. Lecture by Dr. J. A Gorsky: "A Historic Inquest and a Historic Exhumation."

LEeDS Division.-At Parkway Hotel, Bramhope, near Leeds Wednesday, October 19, 7.30 for 8 p.m., annual dinner and dance.

LEIGH Division.-At Waterfield's Restaurant, Leigh Road, Leigh, Thursday, October $20,7.30$ for 8 p.m., annual dinner for males only. Male guests are invited.

LIVERPOOL Division.-At Liverpool Medical Institution, Wednesday, October 19, 8.15 p.m., annual general meeting, followed hy social evening. Address by Dr. S. Wand (Chairman of Council, B.M.A.)

LONDONDERRY DIVISION.-At Londonderry and Gransha Hospital, Gransha, Londonderry, Friday. October 21, 8.15 p.m. psychiatric discussion by Dr. D. J. C. Dawson and staff. Subject, "The First Interview." All doctors in the locality are invited.

Mid-Essex Division.-At Army and Navy Hotel, Chelmsford

Wednesday, October 19, 7.30 p.m., annual general meeting.

Election of officers, etc.

North Glamorgan and Brecknock Division.-Joint meeting with Merthyr and Aberdare Valley Medical Society at Treforest Restaurant, Thursday, October 20, 8 p.m.. dinner, followed by an address by Dr. Delfyn Lewis (Whitchurch Hospital).

North Middlesex Division.-At Committee Room, North Middlesex Hospital, Tuesday, October 18, 8.45 p.m., meeting. Film introduced by Dr. F. H. Milner: "Allergy." A talk and general discussion will follow.

North STaffs Division.-At Grand Hotel, Hanley, Tuesday, Octoher 18, 8 p.m, supper meeting. Dr. J. A. C. Wilson : "Disorders of the Pancreas."

Notringhamshire Branch.- -At Portland Building, Nottingham University, Thursday, October 20, 7.30 for 8 p.m., annual dinner.

Scarborough Division.-At Board Room, Scarborough Hospital, Thursday, October 20, 8.30 p.m., Dr. D. Geraint James : Sarcoidosis."

Southampton Division.-At Conference Room, Civic Centre, Wednesday, October 19, 8 p.m., ordinary meeting. Ladies' Night. Talk by Mr. Robert Fabian:" Behind the Scenes at Scotland Yard."

South Bedfordshire Division.-At Halfway House, Luton, Wednesday, October 19,8 for 8.30 p.m., informal dinner. Wives Wednesday,

South-EAST Essex Division.-At Rochford Hospital, Sunday, October 23, 10.30 a.m., clinical ward round conducted by Dr. E. G. Sita Lumsden.

South MiddleseX Division.-At Medical Officers' Mess, West Middlesex Hospital, Wednesday, October 19, 8.30 p.m., wine and cheese tasting and wine bottling party. Guests, including ladies, invited.

South Wales and Monmouthshire Branch.-Joint meeting with Cardiff Division at Cardiff Royal Infirmary, Thursday, Octoher 20,3 p.m., clinical meeting.

STRATFORD Division.- (1) At King George Hospital, Ilford Tuesday, October 18, 8.45 p.m. Meeting of Ilford Medical Society. Dr. A. Elliott: "A Glimpse at the Soviet Health Services." (2) At East Ham Memorial Hospital, Wednesday, Octoher 19, 8.30 p.m. Dr. J. B. Enticknap: "Atheroma-a New Therapeutic Approach." (3) At St. Clement's Church, Ilford, Therapeutic Approach." (3) At St. Clement's Church,

Swansea Division.-(1) At St. David's Church, Morriston, Sunday, October 16, 11 a.m., St. Luke's Day service. (2) At Morriston Hospital, Thursday, October $20,7.30$ for 8 p.m., clinical meeting.

WeMBley Division.-At Board Room, Wembley Hospital, Tuesday, Octoher 18, 8.30 p.m.. Mr. J. S. Callcutt: " Treatment Tuesday, Octoher $18,8.30$ p.m.j pital." Memhers of other Divisions invited.

West DrRaYshire Division.-At Peacock Hotel, Rowsley, Saturday, October 22, 7.30 for 8 p.m., annual dinner.

WeSTMORL AND Division.-At Heaves Hotel, near Kendal, Saturday, October 22, supper club meeting. 7.30 p.m., buffet supner: 8.15 p.m. Professor W. I. C. Morris: "Causes of Cancer of the Cervix" (illustrated).

West Sissex Division.-At the “ George," Crawley. Thursday, Octoher 20. 6.30 p.m., general meeting. Talk by Dr. C. E. Galiagher: "Regional Medical Service of the Ministry of Health."

Correction.-In the report of the proceedings of the Special Representative Meeting (Octoher 8, p. 131). Mr. H. H. LanGsToN is recorded as saying (p. 133), in connexion with retrospective pay for locums in the hospital service, that locumtenent posts " had heen omitted from" hoth the recent interim pay awards. This should have read: "had benefited from." Further on in his speech $\mathrm{Mr}$. Langston referred to the Central Consultants and Snecialists Committee's resolution having gone to the Joint Consultants Committee "which had had an endorsement of the Working Party's report from its constituent hodies." This should have read "from all its other constituent bodies." since the C.C. and $\mathbf{S}$. Committee is a constituent body of the Joint Consultants Committee. 